\title{
Rheometry nutrition and gluten microstructure trends in wheat cultivars
}

\author{
Nadeem HUSSAIN ${ }^{1}$, Talat MAHMOOD ${ }^{2}$, Muhammad LIAQUAT ${ }^{1 \star}$, Naeem SAFDAR ${ }^{3}$, Waqas AHMED ${ }^{4}$, \\ Abdul QAYYUM ${ }^{5 *}$ (D), Kashif Sarfraz ABBASI ${ }^{6}$, Muhammad IMRAN 7,8
}

\begin{abstract}
Wheat based products are consumed as staple food in most the of Asians countries, hence different wheat cultivars are purposely developed to meet the diverse ecological conditions. These cultivars carry difference in their rheometry nutrition and gluten microstructure that affect the overall product quality. In the present investigation ten wheat varieties were selected from two most common ecological zones i.e. rain fed and irrigated. In general, non-significant differences were observed in most of nutritional parameters however, tremendous variations were studied in rheometry and functional features. More than fifteen parameters were linked through Principal Competent Analysis (PCA) which has segregated the cultivars in to four groups. Analyses of secondary structure of gluten were also analysed through Fourier Transform Infrared spectroscopy (FTIR) and hierarchical cluster for FTIR gluten structure divided wheat cultivars in three groups. Results revealed that wheat cultivars (Borlog-2015 and Zincole-2016) having high protein contents (15\%), more water absorption capacity (72.0\%), dough development time (11.2 $\mathrm{min})$, stability time (15 $\mathrm{min})$ and mixing tolerance index $(11.0 \mathrm{~min})$ made their own cluster and showed variable spectra estimated between the 1750 to $1500 \mathrm{~cm}^{-1}$. On the bases of findings of both PCA model and clustering of FTIR proteins, it was revealed these two cultivars are suited for bread making. In contradiction to above features other two cultivars (Pirsabak-2005 and Wafaq-2001) were found good for making biscuits.
\end{abstract}

Keywords: rheometry nutrition; FTIR proteins; PCA model; wheat secondary structure.

Practical Application: Wheat and its food products are most lavishly consumed across the globe due to its unique nutrition and binding capability predominately outcomes of starch-gluten matric. Both of these features were highly influence by the type of cultivars and agrological conditions in which they grown. Findings on the bases of PCA model and clustering of FTIR proteins revealed that cultivars (Borlog-2015 and Zincole-2016) having high protein are suited for bread making and other fermented cereal products, while cultivars (Pirsabak-2005 and Wafaq-2001) having low protein were found good for making biscuits and cookies.

\section{Introduction}

Wheat (Triticum aestivum L.) is an important cereal grain crop cultivated and consumed all over the world (Iqbal et al., 2015). It is a major source of food in world fulfilling the $20 \%$ of the caloric need of its population (Food and Agriculture Organization, 2003). It is either consumed as chapatti in south Asian regions or as the major ingredient in bakery products in other parts of world (David et al., 2015). Its production and consumption is on increase and according to Statista (2020) world wheat production in 2019-20 is 751 mMTs with $60 \mathrm{~kg}$ per capita per year consumption. Number of United Nations agencies and research groups are working across the globe to develop new and improved indigenous cultivars. Although nutritional, rheological and functional attributes are genetic but majority of them are also influenced by agro ecological conditions of growing areas (Uphoff, 2013).

Amongst cereals wheat is the only crop that has gluten protein composed of gliadins and glutenins fractions. Gluten has properties to hydrate and offers viscoelastic network with starch thus helps in gas retention for appropriate bread volume (Makawi et al., 2013). These characteristics are collectively called as rheometery characteristics specifically important for baking. Amongst, viscosity and elasticity confer preservative specifications, predict dough behaviour during processing and determine the quality of end products (Iqbal et al., 2015).

Bread is predominant wheat based staple food across the globe, supplying daily energy requirements, proteins, minerals and vitamins (Chamandoost et al., 2015). Its quality evaluation has an important role in public health (Dekhordi et al., 2017) due to its high daily consumption per capita (314-505 g per day). Biscuits are another value added wheat based product with wider

\footnotetext{
Received 03 Nov., 2020

Accepted 04 Dec., 2020

${ }^{1}$ Department of Food Science and Technology, The University of Haripur, Haripur, Pakistan

${ }^{2}$ Food and Nutrition Division, Nuclear Institute for Food and Agriculture - NIFA, Peshawar, Pakistan

${ }^{3}$ Food Science Research Institute, National Agricultural Research Centre - NARC, Islamabad, Pakistan

${ }^{4}$ Department of Microbiology, The University of Haripur, Pakistan

${ }^{5}$ Department of Agronomy, The University of Haripur, Haripur, Pakistan

${ }^{6}$ Institute of Food and Nutritional Sciences, PMAS-Arid Agriculture University Rawalpindi, Rawalpindi, Pakistan

${ }^{7}$ Massachusetts Institute of Technology - MIT, Cambridge, MA, United States

${ }^{8}$ Department of Microbiology, Quaid-I-Azam University, Islamabad, Pakistan

*Corresponding author: mliaquat@uoh.edu.pk, aqayyum@uoh.edu.pk
} 
consumption base, relatively long shelf-life, more convenience and good eating quality. It is observed that biscuits made from whole wheat flour are nutritionally superior to those prepared from white flour (Qayyum et al., 2017). Although, wheat composition especially gluten protein in wheat varieties is a genetic characteristic but its quality is highly influence by environmental factors and agronomic practices which in turns effect the product quality (Ade et al., 2012).

Principal Component Analysis (PCA) is an important tool for ecological assessment because most of environmental studies are characteristic of a large number of variables which make it difficult to highlight important trends in the data. PCA sorts out the data into groups of variables with the strongest correlations as reflected by the factor score. The groups otherwise called principal components are ranked in the order of total variance explained.

In the present investigation a PCA model was developed through the correlation of physio-chemical, rheological and functional attributes. Most of the wheat cultivars in the world are developed on the bases of per acre or hector production. This model will help food processors to select wheat cultivar suitable for their baking properties.

\section{Materials and methods}

\subsection{Samples collection}

Five rain fed wheat varieties including NARC-2009, Pak-2013, Shahkar-2013, Pirsabak-2005 and Wafaq-2001 and five irrigated wheat varieties including NARC-2011, Punjab-2011, Galaxy-2013, Borlog-2016, and Zincole-2016 were selected from Wheat Program of National Agriculture Research Centre (NARC) Islamabad, Pakistan. These varieties were selected due to their climatic adaptability and commercial acceptability in the country.

\subsection{Sample preparation}

The tempering of grains at $14.5 \%$ moisture level for all wheat varieties was carried out according to AACC method No. 26-95. Brabender Quadrumate Senior Mill (C.W. Brabender Instruments, Inc.) was used for milling of tempered wheat and fractionated into four parts viz. break flour, reduction flour, shorts and bran. The fractions were weighed and their percentage was calculated on the origin of total material recovered according to AACC-method No. 26-21A (American Association of Cereal Chemists, 2000).

\subsection{Physio-chemical analysis of wheat cultivars}

Physio-chemical analysis was performed according to methods as given International Organization for Standardization (2000). Physical parameters like broken and normal grains were separated manually from 100 gram sample and then weighed on electronic weighing balance and results were expressed in percentage according to method "ISO 7970-2000(B)". Thousand Kernel weight was measured according to method "ISO 520-1977(E)". Thousand kernels were taken randomly and weighed on electronic weighing balance and expressed in gram per 1000 kernels. The Test Weight of ten wheat varieties was recorded by using Test weight apparatus according to method "ISO 7971-2: 1995(E)" and expressed in kilogram per hectoliter (kg/hl). Similarly, chemical analysis like crude protein, crude fat, crude fiber, moisture and ash content were evaluated by following their respective methods mentioned in American Association of Cereal Chemists (2000).

\subsection{Rheological properties of wheat cultivars}

Dough rheology of wheat flour samples were tested by using Farinograph (Brabender D-4100 SEW; Germany) according to the procedure mentioned in AACC-method No. 54-21 (American Association of Cereal Chemists, 2000). The data was recorded about water absorption, dough stability, dough development time, softening and mixing tolerance index. In addition, falling numbers and wet/ dry gluten were also measured. Falling number in flour sample were calculated by the using falling number apparatus, Model No. 1600 according to AACC- method No. 56-81B. Wet and dry gluten were estimated according to method "AACC No.38-12" using Glutamatic Gluten Index and Glotorok 2020. The total wet gluten and dry gluten contents were calculated according through following Expression 1 and 2:

Wet gluten contents $\%=$ Total wet gluten $(\mathrm{g}) \times 860100-\%$ sample moisture
Dry gluten contents $\%=$ Total dry gluten $(\mathrm{g}) \times 860100-\%$ sample moisture

\subsection{Physio-chemistry of wheat gluten by Fourier Transform Infrared Spectroscopy (FTIR)}

Wheat gluten of each wheat variety was subjected to physiochemistry by FTIR as the method described by Zhang et al. (2012). Gluten samples were brought to equilibrium with $1 \mathrm{~mL}$ of water for $48 \mathrm{hrs}$ and then paste was developed by adding $2 \mathrm{~mL}$ water. Infrared Spectra were obtained by using Spectrum one FTIR spectrometer (PerkinElmer, Waltham, MA, USA). Second derivative function was to analyse the amide III regions (1350-1200 $\left.\mathrm{cm}^{-1}\right)$ and Omnic software 8.2 (Thermo Fisher Scientific Inc., Waltham, MA, USA) was used for the interpretation of FTIR spectra. The derivative spectra were obtained from the eleven points, two-degree polynomial function and then inverted by multiplying with 1 . Finally, the hierarchical clustering was done with XL-STAT 2016.

\subsection{Statistical analysis}

Principal Component Analysis (PCA) chart model was developed by using methods as describes by Jolliffe (2002). Initially, all data obtained for physical and proximate analysis was analysed by Two Factors Factorial experiments in Completely Randomized Design (CRD). Least significant difference among the means values was estimated by Duncan's multiple range test (DMRt) as per the guidelines provide by Steel et al. (1997).

\section{Results and discussion}

\subsection{Physiochemical characteristics of wheat cultivars}

Data for physiochemical characteristics was shown in the Table 1 where in a significant difference amongst the wheat varieties were observed for tested parameters. Changes in thousand kernel weight, test weight, normal and damage grains 
Table 1. Differentiation in wheat varieties grown in irrigated and rain fed areas of Pakistan on the bases of physiochemical parameters applied for selection of wheat varieties for production of Bakery products.

\begin{tabular}{|c|c|c|c|c|c|c|c|c|c|}
\hline \multirow[b]{2}{*}{ Varieties } & \multicolumn{4}{|c|}{ Physical Parameters } & \multicolumn{5}{|c|}{ Chemical Parameters } \\
\hline & Test Weight & $\begin{array}{c}\text { Thousand } \\
\text { Kernel } \\
\text { Weight }\end{array}$ & $\begin{array}{c}\text { Damage } \\
\text { Grains }\end{array}$ & Normal grain & Moisture\% & Ash \% & Protein \% & Fat $\%$ & Fiber \% \\
\hline $\begin{array}{l}\text { NARC-2009 } \\
\text { (RF) }\end{array}$ & $67.0 \pm 0.020^{\mathrm{e}}$ & $32.07 \pm 0.31^{\mathrm{d}}$ & $15.20 \pm 0.48^{\mathrm{a}}$ & $80.09 \pm 0.43^{\mathrm{f}}$ & $12.22 \pm 1.14^{\mathrm{a}}$ & $1.8 \pm 0.32^{\mathrm{ab}}$ & $13.45 \pm 0.07^{c}$ & $2.10 \pm 1.22^{\mathrm{a}}$ & $2.19 \pm 1.40^{c}$ \\
\hline $\begin{array}{l}\text { Pak-2013 } \\
\text { (RF) }\end{array}$ & $69.0 \pm 0.024^{\mathrm{de}}$ & $33.20 \pm 0.21^{\mathrm{d}}$ & $04.58 \pm 0.27^{\mathrm{ef}}$ & $91.69 \pm 0.50^{\mathrm{cd}}$ & $11.70 \pm 0.16^{\mathrm{a}}$ & $1.6 \pm 0.39^{b c}$ & $11.64 \pm 0.00^{\mathrm{e}}$ & $1.75 \pm 0.39^{c}$ & $2.65 \pm 0.93^{\mathrm{a}}$ \\
\hline $\begin{array}{l}\text { Shahkar- } \\
\text { 2013(RF) }\end{array}$ & $76.0 \pm 1.22^{\mathrm{abc}}$ & $33.03 \pm 0.49^{d}$ & $02.95 \pm 0.12^{g}$ & $92.65 \pm 0.21^{\mathrm{bc}}$ & $11.03 \pm 1.07^{\mathrm{b}}$ & $1.3 \pm 0.00^{\mathrm{d}}$ & $11.10 \pm 0.00^{\mathrm{f}}$ & $1.97 \pm 0.02^{\mathrm{b}}$ & $2.23 \pm 0.00^{\mathrm{b}}$ \\
\hline $\begin{array}{l}\text { Pirsabak- } \\
\text { 2005(RF) }\end{array}$ & $76.3 \pm 1.34^{\mathrm{abc}}$ & $34.84 \pm 0.30^{\mathrm{d}}$ & $05.74 \pm 1.29^{\mathrm{d}}$ & $90.62 \pm 1.17^{\mathrm{d}}$ & $09.80 \pm 0.02^{e}$ & $1.5 \pm 1.39^{\text {cd }}$ & $10.30 \pm 0.0^{g}$ & $1.08 \pm 0.23^{e}$ & $2.14 \pm 0.27^{\mathrm{b}}$ \\
\hline $\begin{array}{l}\text { Wafaq- } \\
\text { 2001(RF) }\end{array}$ & $81.7 \pm 0.39^{\mathrm{a}}$ & $32.46 \pm 1.38^{\mathrm{d}}$ & $09.37 \pm 1.10^{\mathrm{b}}$ & $86.99 \pm 0.46^{\mathrm{e}}$ & $10.90 \pm 0.02_{\mathrm{b}}$ & $1.6 \pm 0.00^{b c}$ & $10.24 \pm 0.51^{g}$ & $1.05 \pm 0.46^{\mathrm{d}}$ & $2.16 \pm 0.01^{\mathrm{b}}$ \\
\hline $\begin{array}{l}\text { NARC-2011 } \\
\text { (IR) }\end{array}$ & $73.0 \pm 0.34^{\text {cde }}$ & $34.56 \pm 0.22^{\mathrm{d}}$ & $04.04 \pm 0.51^{\mathrm{f}}$ & $94.86 \pm 0.38^{\mathrm{a}}$ & $12.20 \pm 0.46^{\mathrm{a}}$ & $1.6 \pm 1.22^{b c}$ & $11.02 \pm 0.16^{\mathrm{f}}$ & $1.81 \pm 0.31^{\mathrm{c}}$ & $2.41 \pm 0.34^{\mathrm{b}}$ \\
\hline $\begin{array}{l}\text { Punjab- } \\
\text { 2011(IR) }\end{array}$ & $81.0 \pm 1.34^{\mathrm{ab}}$ & $44.61 \pm 0.09^{b}$ & $04.58 \pm 1.34^{e^{e f}}$ & $93.85 \pm 1.18^{\mathrm{ab}}$ & $12.20 \pm 0.27^{\mathrm{a}}$ & $1.5 \pm 0.71^{\mathrm{b}}$ & $12.23 \pm 0.00^{\mathrm{d}}$ & $1.96 \pm 0.39^{b}$ & $2.24 \pm 0.46^{c}$ \\
\hline $\begin{array}{l}\text { Galaxy- } \\
\text { 2013(IR) }\end{array}$ & $79.0 \pm 0.71^{\mathrm{abc}}$ & $49.92 \pm 0.12^{\mathrm{a}}$ & $07.42 \pm 1.20^{c}$ & $91.70 \pm 1.39^{\mathrm{cd}}$ & $12.03 \pm 1.30^{\mathrm{a}}$ & $1.3 \pm 0.56^{\mathrm{d}}$ & $11.03 \pm 0.27^{\mathrm{f}}$ & $2.01 \pm 0.10^{\mathrm{b}}$ & $1.65 \pm 1.07^{\mathrm{d}}$ \\
\hline $\begin{array}{l}\text { Borlog- } \\
\text { 2016(IR) }\end{array}$ & $73.0 \pm 0.05^{\text {cde }}$ & $48.06 \pm 1.14^{\mathrm{a}}$ & $05.29 \pm 1.28^{\mathrm{de}}$ & $90.77 \pm 1.39^{\mathrm{d}}$ & $10.40 \pm 0.27^{\mathrm{cd}}$ & $1.9 \pm 0.95^{\mathrm{a}}$ & $15.10 \pm 0.19^{\mathrm{b}}$ & $1.95 \pm 0.20^{\mathrm{b}}$ & $2.41 \pm 1.37^{\mathrm{b}}$ \\
\hline $\begin{array}{l}\text { Zincole- } \\
2016 \text { (IR) }\end{array}$ & $75.0 \pm 1.22^{\mathrm{bcd}}$ & $38.60 \pm 0.85^{c}$ & $05.92 \pm 0.72^{\mathrm{d}}$ & $88.25 \pm 0.49^{e}$ & $10.40 \pm 0.02^{\mathrm{cd}}$ & $1.97 \pm 1.30^{\mathrm{a}}$ & $15.63 \pm 0.16^{a}$ & $1.22 \pm 1.36^{\mathrm{d}}$ & $2.49 \pm 0.10^{\mathrm{b}}$ \\
\hline
\end{tabular}

RF stands for rain fed and IR stands for irrigated varieties. Values represented as mean \pm SE of three replicates. Values in columns having the same letters were not significantly different at $\mathrm{p} \leq 0.05$

were observed in both cultivars groups. The results for our studies were in agreement with the findings of Khan et al. (2015) who reported physical parameters are under genetic control however, environment factors also affect over all grains quality parameters. Similarly, Iqbal et al. (2015) also reported that difference is due to the genetic makeup and it seemed that there is no effect of irrigated and rain fed pattern on this parameter.

Results regarding chemical parameters showed significance difference among all the varieties (Table 1). The moisture contents in different wheat varieties were in ranged of 9.8-12.21\%. There were significantly high moisture contents in NARC-2009 (12.21\%) however; the lowest moisture contents were founded in Pirsabak-2005 (9.8\%). Similarly, variable trends were observed for ash, protein, fibre and fat amongst both groups. Higher ash content was present in in Zincole-2016 (1.97\%) while the lowest was found in Galaxy-2013 (1.3\%). Crude protein was higher in irrigated area (Zincole-2016, 15.63\%) while fat contents were higher in rain fed wheat varieties (NARC-2009; 2.1\%). Fiber contents were randomly distributed in both rain fed and irrigated areas that might be due to the genetic make of each variety. Results of present investigation are in line with the finding of Khan et al. (2015) who reported variations in the proximate composition in wheat varieties grown in Pakistan. Wheat varieties and growing atmospheric conditions are decisive factors controlling nutritional contents of wheat. It exhibited inverse relationship with the quality mainly milling process (Iqbal et al., 2015). Our results are also in line with the findings of Hernandez-Espinosa et al. (2020) who studied nutritional quality characteristics of a set of durum wheat land races from Iran and Mexico.

\subsection{Rheological characterization of wheat cultivars}

Results of rheological traits were shown in the Table 2. It was observed that range of wet gluten and dry gluten was estimated between $23.13-42.7 \%$ and $6.1-13.56 \%$ respectively. There was significant difference among all wheat varieties for both dry and wet gluten contents. Results of this investigation were also in accordance with the previous study of Rahil et al. (2015) who reported higher protein contents in selected wheat cultivars. Wheat flour quality is dependent upon the gluten content which plays significant role in baking quality of bread. Falling number estimated in all varieties was more than 400s seconds which was in agreement with the findings of Qayyum et al. (2017) who reported higher values for falling numbers (430s). Lower falling number value indicated higher $\alpha$-amylase activity that results in low starch availability for gluten protein thereby causing poor visco-elastic characteristics of dough. Farinograhic studies also revealed that water absorption capacity of all the wheat flour was significantly different from each other. The higher water absorption (70.6\%) was recorded in Zincole-2016 and lowest in NARC-2009. These results were in lined with Channa et al. (2015) who reported $45-79 \%$ water absorption. The higher water absorption is due to high protein content as reported by Iqbal et al. (2015). Similarly, it was revealed from the farinogram that different varieties showed significant variation in their dough development time (DDT), dough stability (DS), mixing tolerance index (MTI), departure time (DT) and FQN No. Zincole-2016 exhibited higher mean values for DDT (11.5 $\mathrm{min}$ ) as compared to other wheat varieties with 1.4-16.2 min. DS time. The mixing tolerance index (MTI), departure time (DT) and FQN No. of all wheat varieties was found significant different in tested 
Table 2. Differentiation in wheat varieties grown in irrigated and rain fed areas of Pakistan on the bases of functional and farinographic properties applied for selection of wheat varieties for production of Bakery products.

\begin{tabular}{|c|c|c|c|c|c|c|c|c|c|}
\hline \multirow[b]{2}{*}{ Varieties } & \multicolumn{3}{|c|}{ Functional Properties } & \multicolumn{6}{|c|}{ Farinographic Properties } \\
\hline & Wet gluten $\%$ & Dry gluten \% & $\begin{array}{l}\text { Falling } \\
\text { number } \\
\text { (seconds) }\end{array}$ & $\begin{array}{l}\text { Departure } \\
\text { time (DT) }\end{array}$ & FQN NO. & $\begin{array}{c}\text { Water } \\
\text { absorption } \\
\%\end{array}$ & $\begin{array}{c}\text { Dough } \\
\text { development } \\
\text { time (DDT) } \\
(\mathrm{min})\end{array}$ & $\begin{array}{l}\text { Dough } \\
\text { Stability } \\
\text { (Min) }\end{array}$ & $\begin{array}{c}\text { Mixing } \\
\text { tolerance } \\
\text { index (MTI) } \\
(\text { Min }) \\
\end{array}$ \\
\hline $\begin{array}{l}\text { NARC-2009 } \\
\text { (RF) }\end{array}$ & $36.10 \pm 0.27^{\mathrm{b}}$ & $13.5 \pm 0.39^{a}$ & $497.0 \pm 1.04^{\mathrm{bc}}$ & $14.0 \pm 1.37^{\mathrm{abc}}$ & $200 \pm 0.46^{a}$ & $52.0 \pm 0.08^{g}$ & $6.9 \pm 0.71^{\mathrm{cd}}$ & $7.7 \pm 0.46^{\mathrm{d}}$ & $19.7 \pm 0.39^{\mathrm{cd}}$ \\
\hline $\begin{array}{l}\text { Pak-2013 } \\
\text { (RF) }\end{array}$ & $32.80 \pm 0.34^{\mathrm{c}}$ & $9.7 \pm 0.19^{b}$ & $413.7 \pm 0.14^{\mathrm{efg}}$ & $6.6 \pm 0.46^{c}$ & $65 \pm 0.16^{d}$ & $53.4 \pm 0.86^{\mathrm{f}}$ & $1.4 \pm 0.71^{\mathrm{g}}$ & $1.4 \pm 1.22^{g}$ & $24.0 \pm 0.71^{\mathrm{c}}$ \\
\hline $\begin{array}{l}\text { Shahkar- } \\
\text { 2013(RF) }\end{array}$ & $24.80 \pm 0.03^{\mathrm{d}}$ & $8.3 \pm 0.19^{c}$ & $429.0 \pm 0.34^{\mathrm{e}}$ & $10.7 \pm 0.46^{\mathrm{abc}}$ & $107 \pm 0.39^{c}$ & $68.1 \pm 0.27^{c}$ & $5.8 \pm 0.56^{\mathrm{e}}$ & $8.5 \pm 0.01^{c}$ & $33.0 \pm 0.01^{\mathrm{b}}$ \\
\hline $\begin{array}{l}\text { Pirsabak- } \\
\text { 2005(RF) }\end{array}$ & $23.70 \pm 0.27^{\mathrm{de}}$ & $7.2 \pm 0.31^{\mathrm{e}}$ & $386.7 \pm 1.26^{\mathrm{g}}$ & $10.0 \pm 0.20^{\mathrm{bc}}$ & $100 \pm 1.41^{\mathrm{c}}$ & $67.7 \pm 1.37^{c}$ & $6.3 \pm 0.71^{\mathrm{de}}$ & $7.0 \pm 1.41^{\mathrm{e}}$ & $46.0 \pm 0.01^{\mathrm{a}}$ \\
\hline $\begin{array}{l}\text { Wafaq- } \\
\text { 2001(RF) }\end{array}$ & $41.56 \pm 0.25^{\mathrm{a}}$ & $6.1 \pm 0.00^{f}$ & $424.0 \pm 0.24^{\mathrm{ef}}$ & $10.2 \pm 0.41^{\mathrm{abc}}$ & $102 \pm 0.27^{c}$ & $66.0 \pm 1.41^{\mathrm{d}}$ & $5.7 \pm 1.22^{\mathrm{e}}$ & $7.7 \pm 1.07^{\mathrm{d}}$ & $32.0 \pm 0.01^{\mathrm{b}}$ \\
\hline $\begin{array}{l}\text { NARC-2011 } \\
\text { (IR) }\end{array}$ & $19.26 \pm 1.34^{\mathrm{f}}$ & $6.3 \pm 0.00^{f}$ & $468.0 \pm 1.30^{\mathrm{cd}}$ & $5.3 \pm 1.26^{c}$ & $53 \pm 0.93^{e}$ & $53.7 \pm 1.34^{\mathrm{f}}$ & $2.2 \pm 0.93^{\mathrm{f}}$ & $1.8 \pm 0.46^{g}$ & $35.0 \pm 1.22^{\mathrm{b}}$ \\
\hline $\begin{array}{l}\text { Punjab- } \\
2011(I R)\end{array}$ & $31.67 \pm 1.22^{c}$ & $9.7 \pm 0.36^{\mathrm{b}}$ & $396.0 \pm 0.34^{\mathrm{g}}$ & $20.0 \pm 1.41^{\mathrm{a}}$ & $200 \pm 0.71^{a}$ & $56.9 \pm 1.39^{e}$ & $7.5 \pm 0.01^{b c}$ & $6.1 \pm 0.46^{\mathrm{f}}$ & $20.0 \pm 0.71^{\text {cd }}$ \\
\hline $\begin{array}{l}\text { Galaxy- } \\
\text { 2013(IR) }\end{array}$ & $23.10 \pm 0.03^{e}$ & $7.6 \pm 0.14^{\mathrm{d}}$ & $574.0 \pm 1.22^{\mathrm{a}}$ & $17.8 \pm 0.12^{\mathrm{ab}}$ & $178 \pm 0.19^{b}$ & $54.1 \pm 0.46^{\mathrm{f}}$ & $7.7 \pm 0.46^{\mathrm{b}}$ & $7.0 \pm 0.27^{\mathrm{e}}$ & $16.0 \pm 0.01^{\mathrm{e}}$ \\
\hline $\begin{array}{l}\text { Borlog- } \\
\text { 2016(IR) }\end{array}$ & $42.70 \pm 0.46^{\mathrm{a}}$ & $13.2 \pm 0.14^{\mathrm{a}}$ & $514.7 \pm 0.51^{\mathrm{b}}$ & $20.0 \pm 1.2^{\mathrm{a}}$ & $200 \pm 0.59^{\mathrm{a}}$ & $72.0 \pm 1.41^{\mathrm{a}}$ & $11.2 \pm 0.01^{\mathrm{a}}$ & $15.0 \pm 1.41^{\mathrm{b}}$ & $11.0 \pm 0.01^{\mathrm{f}}$ \\
\hline $\begin{array}{l}\text { Zincole- } \\
\text { 2016(IR) }\end{array}$ & $41.50 \pm 1.34^{\mathrm{a}}$ & $13.4 \pm 0.24^{\mathrm{a}}$ & $441.0 \pm 0.34^{\mathrm{de}}$ & $20.0 \pm 0.13^{\mathrm{a}}$ & $200 \pm 1.41^{\mathrm{a}}$ & $70.6 \pm 0.01 b$ & $11.5 \pm 0.01^{\mathrm{a}}$ & $16.0 \pm 1.41^{\mathrm{a}}$ & $12.3 \pm 0.27^{\mathrm{ef}}$ \\
\hline
\end{tabular}

wheat cultivars. Pirsabak-2005 has higher mixing tolerance index value (46 BU) while Borlog-2016 has the lowest (11BU). The rheological properties estimated in the current study were also in agreement with the findings of Channa et al. (2015) and Iqbal et al. (2015).

\subsection{Rheometry nutrition: a general trends in wheat cultivars as determined by PCA model}

In order to investigate general trend among the rain-fed and irrigated wheat varieties in terms of their tested parameter principal competent analysis (PCA) was employed. Schematic figures were developed by correlating physio-chemical and rheological attributes. More than fifteen parameters were linked through PCA which revealed four principal groups of cultivars. Cultivars like Galaxy-2013, NARC-2011 and Pak-2013 were kept in the first group having little variation in their moisture contents. In the second group, Punjab-2011 and NARC-2009 were kept having close relationship with third group in term of FQN NO, DT and protein contents. In contrast, rain fed varieties showed higher values for their falling number and MTI falling numbers and grouped in fourth category. Some wheat varieties of irrigated and rain fed region have little variation in their fat contents and water absorption capacity. However, these varieties are different from Borlog-2016 and Zincole-2016 who have DDT (time), ash gluten etc. are on the same plan. On the bases of inter-relationship and intra-relationship among the tested parameters two wheat varieties were screened for bread (Borlog-2015 and Zincole-2016) and other two (Pirsabak-2005 and Wafaq-2001) were for biscuit preparation. PCA also helped to reveal some relationships between wheat properties and ecological conditions. It has proved to be useful approach for the characterization of rainfed and irrigated wheat cultivars on the basis of their tested quality attributes. Presented PCA model might also equally be applicable for other south Asian countries especially India due to similar climatic conditions. Previously, this PCA model was applied by Ciccoritti et al. (2011) to determine the relationship between environmental conditions and genotypes in durum wheat.

\subsection{Physio-chemistry of wheat Gluten by FTIR and hierarchical cluster analysis}

Gluten microstructure based on FTIR spectra for wheat varieties grown in rain fed and in irrigated is presented in Figure 1. Infrared spectra in the amide I and amide II bands revealed that there was difference in the gluten contents of wheat grown in the rain fed and irrigated areas. Major shift in the intensity/AU was observed in the bands between the wave lengths of 1750 to $1500 \mathrm{~cm}^{-1}$. It was noted that amide one appeared as most intensive absorption band in the protein. It was regulated by stretching vibrations of $\mathrm{C}=\mathrm{O}$ and $\mathrm{C}-\mathrm{N}$ groups and present in the range of $1600-1700 \mathrm{~cm}^{-1}$. Similarly, Amide II was also found in the 1500 to $1600 \mathrm{~cm}^{-1}$. This is mainly due to $\mathrm{N}-\mathrm{H}$ bonding and other potential groups are $\mathrm{C}-\mathrm{N}$ and $\mathrm{C}-\mathrm{C}$ but with low stretching vibrations as also expressed by Zhang et al. (2012). In our investigation, the variation in the signal intensity might be attributed to molecular polymerization due to water stress in rain fed wheat cultivars. Hierarchical cluster analysis for wheat varieties was shown in the Figure 2 which revealed 


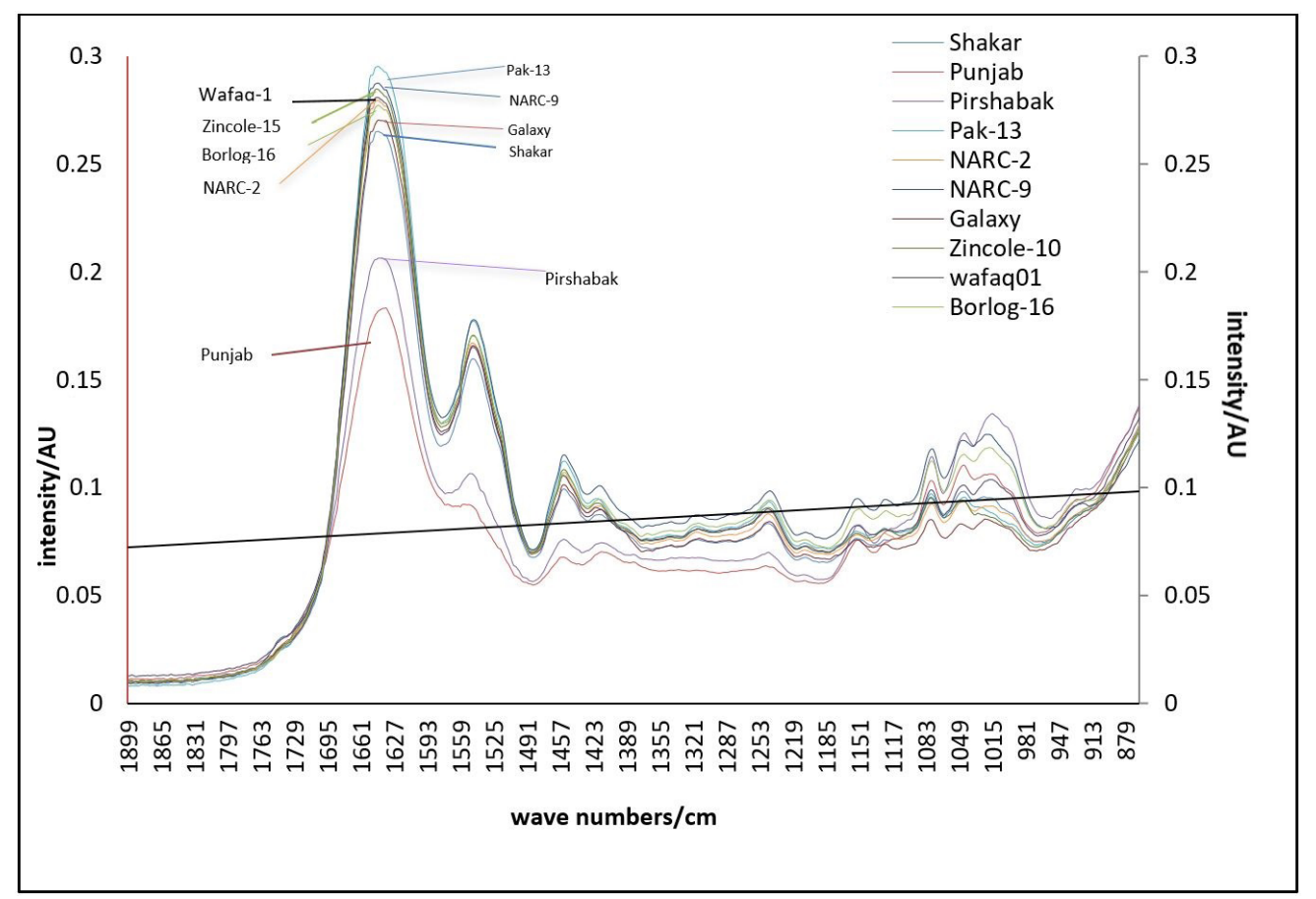

Figure 1. Secondary structure of FTIR spectrum of gluten isolated from wheat grown in irrigated and rain fed areas of Pakistan indicating that major shift in the intensity/AU was in the band was observed between the waves lengths of 1750 to 1500 wave number/cm.

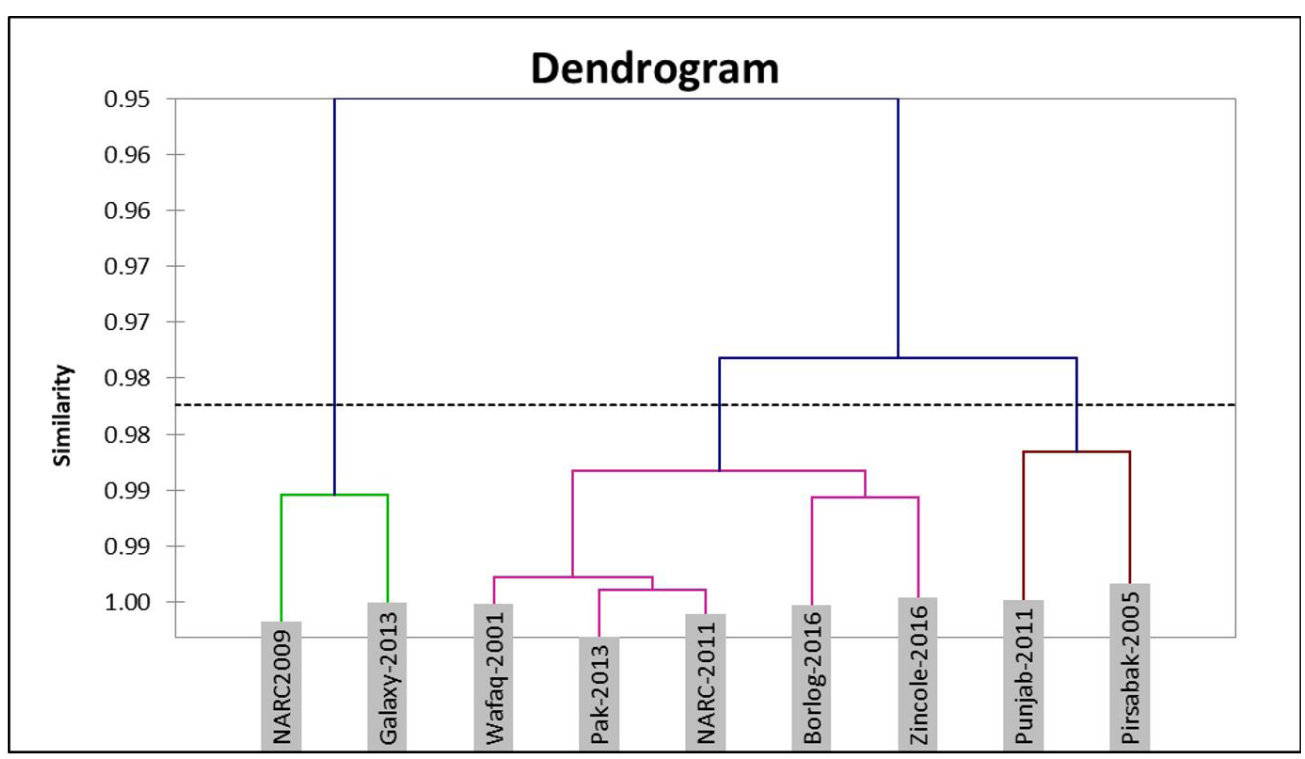

Figure 2. Hierarchical clustering analysis of FTIR data indicating that both rain fed and irrigated wheat are grouped at various similarities levels.

that both rain fed and irrigated wheat are grouped at various similarities levels. There were three groups in wheat cultivars on the bases of gluten microstructure. First group was comprised of NARC-2009, Galaxy- 2013, second group contained Wafaq-2001, Pak-2013 and NARC 2011 wherein later two cultivars have no difference in the secondary structure of gluten proteins and they have $100 \%$ similarity whereas Zincole-2016 and Borlog-2015 were also remained part of this group at $99 \%$ similarity by making independent relationship of similarity with each other. Third group contained Punjab-2011 and Pirsaak-2005 which showed
98\% similarity. Generally, all of three groups are clustered at $95 \%$ similarity index. Results of PCA model (Figure 3) for grouping wheat cultivars for rheometry nutrition and hierarchical cluster for FTIR gluten structure were linked with each other. It was revealed that those wheat cultivars (Borlog-2015 and Zincole-2016) that have high water absorption capacity, DDT and MTIs made their own cultured. The results of present finding in lined with finding of Mironeasa \& Codină (2019) studied the dough rheological behaviour and microstructure of wheat flours. 


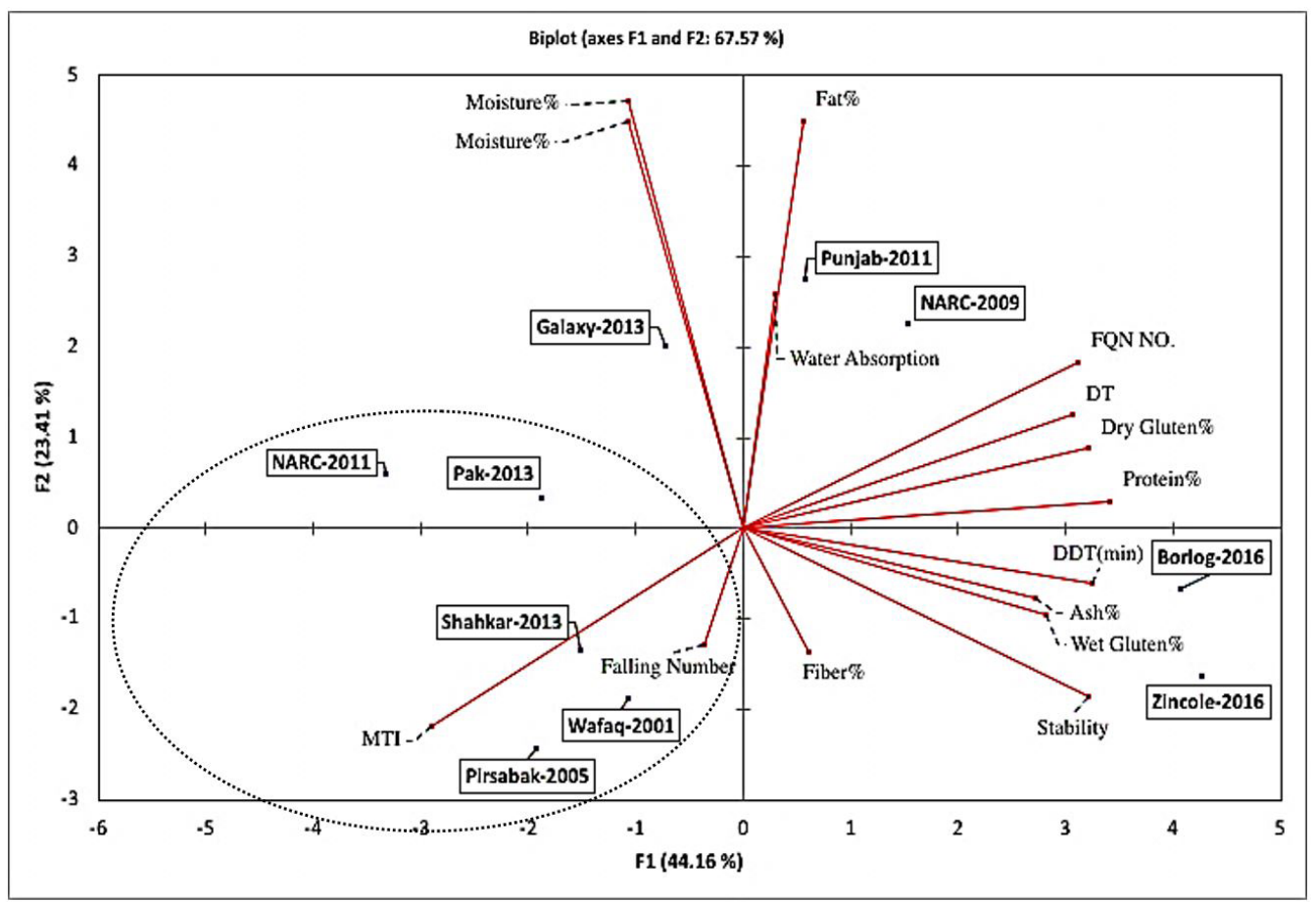

Figure 3. Principal component analysis Principal (PCA) chart model.

\section{Conclusion}

In the present investigation ten wheat varieties from irrigated and rain fed adopted agro-climate were used to determine the impact of these varieties on the quality characteristics of bakery products. PCA model on rheometery nutrition of wheat flour and hierarchical cluster analysis for gluten microstructure was collectively applied for the selection of bested suited variety as per the requirement of products. On the bases of quality characteristics Zincole-2016 and Borlog-2016 were found suitable for bread making and Pirsabak-2005 and Wafaq-2001 suited for biscuit making.

\section{References}

Ade, I. C., Ingbian, E. K., \& Abu, J. O. (2012). Physical, chemical and sensory properties of baked products from blends of wheat and African yam bean (Sphenostylis stenocarpa) water extractable proteins. Nigerian Food Journal, 30(1), 109-115. http://dx.doi.org/10.1016/ S0189-7241(15)30019-9.

American Association of Cereal Chemists - AACC. (2000). Approved methods of American Association of Cereal Chemists. St. Paul: AACC.

Chamandoost, S., Naderi, M., Afshar, H., \& Kamali, K. (2015). Amount of baking soda and salt in bakeries of Zanjan city in 2011-2012. Journal of Human, Environment and Health Promotion, 1(1), 56-64. http://dx.doi.org/10.29252/jhehp.1.1.8.

Channa, M. J., Ghangro, A. B., Sheikh, S. A., \& Nizaman, S. M. (2015). Rhysico-chemical characteristics and rheolgical properties of different wheat varieties grown in Sindh. Pakistan Journal of Analytical \& Environmental Chemistry, 2(16), 1118.

Ciccoritti, R., Scalfati, G., Cammerata, A., \& Sgrulletta, D. (2011). Variations in content and extractability of durum wheat (Triticum turgidum L. var durum) Arabinoxylans associated with genetic and environmental factors. International Journal of Molecular
Sciences, 12(7), 4536-4549. http://dx.doi.org/10.3390/ijms12074536. PMid:21845095.

David, O., Arthur, E., Kwadwo, S. O., Badu, E., \& Sakyi, P. (2015). Proximate composition and some functional properties of soft wheat flour. International Journal of Innovative Research in Science, Engineering and Technology, 4(2), 753-758.

Dekhordi, Z. S., Bazargani-Gilani, B., \& Salari, S. (2017). Quality of flour types, in the bakeries of Hamedan, Iran during 2015-2016. Archives of Hygiene Sciences, 6(2), 206-213. http://dx.doi.org/10.29252/ ArchHygSci.6.2.206.

Food and Agriculture Organization - FAO. (2003). The special programme for food security: responding to new challenges. Rome.

Hernandez-Espinosa, N., Laddomada, B., Payne, T., Huerta-Espino, H., Govindan, V., Ammar, K., Ibba, M. I., Pasqualone, A., \& Guzman, C. (2020). Nutritional quality characterization of a set of durum wheat landraces from Iran and Mexico. Lebensmittel-Wissenschaft + Technologie, 124, 109198. http://dx.doi.org/10.1016/j.lwt.2020.109198.

International Organization for Standardization - ISO. (2000). ISO 7970:2011: wheat (Triticum aestivum L.): specification. Geneva. Retrieved from https://www.iso.org/standard/43302.html

Iqbal, Z., Pasha, I., Abrar, M., Masih, S., \& Hanif, M. S. (2015). Physicochemical, functional and rheological properties of wheat varieties. Journal of Agricultural Research, 53(2), 253-267.

Jolliffe, I. T. (2002). Principal component analysis (Springer Series in Statistics, 2nd ed.). New York: Springer.

Khan, S. A., Memon, N., Deverajani, B. R., \& Baloch, S. (2015). Physicochemical characteristics of wheat grain and their relation with proteins in different varieties cultivated in Sindh. Sindh University Research Journal, 47(4), 839-842.

Makawi, A. B., Mustafa, A. I., \& Ahmed, I. A. M. (2013). Characterization and improvement of flours of three Sudanese wheat cultivars for loaf bread making. Innovative Romanian Food Biotechnology, 13(1), 30-44. 
Mironeasa, S., \& Codină, G. G. (2019). Dough rheological behavior and microstructure characterization of composite dough with wheat and tomato seed flours. Foods, 8(12), 626. http://dx.doi.org/10.3390/ foods8120626. PMid:31801201.

Qayyum, A., Munir, M., Raza, S., Gillani, M., Kanwal, S., Rashid, N., Mumtaz, A., Safdar, N., \& Gillani, Z. (2017). Rheological and qualitative assessment of wheat-pea composite flour and its utilization in biscuits. Pakistan Journal of Agricultural Research, 30(3), 258-265. http://dx.doi.org/10.17582/journal.pjar/2017.30.3.258.265.

Rahil, A., Ali, R., Khan, M. S., Sayeed, S. A., Saeed, J., \& Yousufi, F. (2015). Effect of proteases and carbohydrates on dough rheology and end quality of cookie. American Journal of Food Science and Nutrition Research, 2(2), 62-66.
Statista. (2020, January). Total wheat consumption worldwide from 2017/2018 to 2019/2020 (in million metric tons). Retrieved from https:// www.statista.com/statistics/1094056/total-global-rice-consumption/

Steel, R. D., Torrie, J. H., \& Dickey, D. (1997). Principle and procedure of statistics. a biometrical approach (3rd ed.). New York: McGrawHills Book Co.

Uphoff, N. (Ed.). (2013). Agroecological innovations: increasing food production with participatory development. London: Routledge. http://dx.doi.org/10.4324/9781849770446.

Zhang, H., Claver, I. P., Li, Q., Zhu, K., Peng, W., \& Zhou, H. (2012). Structural modification of wheat gluten by dry heat-enhanced enzymatic hydrolysis. Food Technology and Biotechnology, 50(1), 53-58. 